\title{
SKA2 wt Allele
}

National Cancer Institute

\section{Source}

National Cancer Institute. SKA2 wt Allele. NCI Thesaurus. Code C118353.

Human SKA2 wild-type allele is located in the vicinity of $17 q 23.2$ and is approximately 45 $\mathrm{kb}$ in length. This allele, which encodes spindle and kinetochore-associated protein 2 , is involved in chromosome segregation. 